\title{
Observation of volcanic ash from Puyehue-Cordón Caulle with IASI
}

\author{
L. Klüser, T. Erbertseder, and J. Meyer-Arnek \\ Deutsches Zentrum für Luft- und Raumfahrt (DLR), Oberpfaffenhofen, Germany \\ Correspondence to: L. Klüser (lars.klueser@dlr.de)
}

Received: 4 April 2012 - Published in Atmos. Meas. Tech. Discuss.: 13 June 2012

Revised: 30 November 2012 - Accepted: 5 December 2012 - Published: 4 January 2013

\begin{abstract}
On 4 June 2011 an eruption of the Chilean volcano complex Puyehue-Cordón Caulle injected large amounts of volcanic ash into the atmosphere and affected local life as well as hemisphere-wide air traffic. Observations of the Infrared Atmospheric Sounding Interferometer (IASI) flown on board of the MetOp satellite have been exploited to analyze the evolution of the ash plume around the Southern Hemisphere. A novel singular vector-based retrieval methodology, originally developed for observation of desert dust over land and ocean, has been adapted to enable remote sensing of volcanic ash.

Since IASI observations in the $8-12 \mu \mathrm{m}$ window are applied in the retrieval, the method is insensitive to solar illumination and therefore yields twice the observation rate of the ash plume evolution compared to solar backscatter methods from polar orbiting satellites. The retrieval scheme, the emission characteristics and the circumpolar transport of the ash are examined by means of a source-receptor analysis.
\end{abstract}

\section{Introduction}

Volcanic eruptions can emit large quantities of ash particles and gases, such as $\mathrm{H}_{2} \mathrm{O}, \mathrm{CO}_{2}$ or $\mathrm{SO}_{2}$, into the atmosphere. Depending on the injection height, volcanic ash can remain up to several weeks in the troposphere and up to months in the stratosphere. According to Halmer and Schmincke (2003), $80 \%$ of ash emissions from explosive volcanic eruptions exceed altitudes of $6 \mathrm{~km}, 60 \%$ of $10 \mathrm{~km}$ and $20 \%$ altitudes of $15 \mathrm{~km}$. Therefore, volcanic ash may also be subject to long-range transport in the free troposphere and stratosphere.

In ambient air, volcanic ash poses a severe health risk to human beings and animals (Horwell and Baxter, 2006). Moreover, volcanic ash has proven to be a hazard to aviation
(Miller and Casadevall, 2000). Depending on its concentration and composition it can strongly reduce visibility, clog the sensors of the aircraft, disturb the avionics and in the worst case lead to a failure of turbojet engines (Swanson and Beget, 1991).

In the past more than 90 aircraft were damaged after flying through volcanic ash plumes. The total cost of the damage to aircraft in the period 1982-2000 is estimated at 250 million US dollars, but so far none of the incidents have resulted in fatal accidents (van Geffen et al., 2007). The eruption of the Icelandic volcano Eyjafjalla in March and April 2010 and the closure of the European air space has clearly demonstrated the vulnerability of the economy to such an air disaster (Zehner, 2010). Moreover, it has demonstrated the importance of satellite data for tracking and early warning of volcanic emissions and, in particular, ash plumes.

Very often observations of $\mathrm{SO}_{2}$ and the ultraviolet aerosol absorbing index (Torres et al., 1998) have been used operationally as a proxy for the location of volcanic ash from satellite instruments like the Total Ozone Monitoring Spectrometer (TOMS), the Global Ozone Monitoring Experiment (GOME, GOME-2), Scanning Imaging Absorption Spectrometer for Atmospheric Cartography (SCIAMACHY) and the Ozone Monitoring Instrument (OMI) (e.g. Krueger, 1983; Thomas et al., 2005; Loyola et al., 2008; Rix et al., 2009; Krotkov et al., 2006).

Mineral aerosol extinction in the thermal infrared window is mainly caused by $\mathrm{Si}-\mathrm{O}$ resonance absorption around $9.5 \mu \mathrm{m}$ in silicates (e.g. Hudson et al., 2008a, b). Like desert dust, volcanic ash is largely composed of silicate materials (e.g. Pettijohn et al., 1972; Horwell and Baxter, 2006; Prata and Kerkmann, 2007). Prata (1989) showed that infrared split window satellite observations can be used to detect volcanic ash plumes. Different approaches to exploiting differential volcanic ash absorption in infrared satellite 
observations for ash detection have been applied to volcanic eruptions since (e.g. Wen and Rose, 1994; Hilger and Clarke, 2002; Corradini et al., 2009; Karagulian et al., 2010). Recently, the Infrared Atmospheric Sounding Interferometer (IASI) on MetOp has been applied to observe volcanic $\mathrm{SO}_{2}$ and to successfully detect volcanic ash, e.g. from the Chaiten (Chile, 2008), Kasatochi (Aleutian Islands, 2008) and Eyjafjalla (Iceland, 2010) eruptions (e.g. Clarisse et al., 2008, 2012; Gangale et al., 2010; Karagulian et al., 2010).

In this paper the adaptation of a novel retrieval method for mineral dust to volcanic ash is presented. It enables remote sensing of volcanic ash aerosol optical depth (AOD) with IASI. The method is applied to a plinian eruption from a fissure in the Puyehue-Cordón Caulle Volcanic Complex in central Chile, which began on 4 June 2011 at 19:15 UTC (SERNAGEOMIN, 2011). Hereafter the eruption will be referred to as PCCE (Puyehue-Cordón Caulle eruption). It caused ash fall over South America and widespread air space closure over South Africa, Australia and New Zealand as well. The ash plume could be detected south of Australia some days after the eruption and reached the Chilean coast from westerly directions again on 14 June 2011 after circumpolar transport.

After this introduction the ash retrieval method for IASI is described in Sect. 2, followed by observations and analysis of the PCCE ash plume. After a discussion in Sect. 4, conclusions are drawn in Sect. 5.

\section{The SVD based volcanic ash retrieval method from IASI}

The Infrared Atmospheric Sounding Interferometer (IASI) is a Michelson interferometer developed for atmospheric sounding in the thermal infrared spectrum (Larar et al., 2010). It has a spectral resolution of $0.5 \mathrm{~cm}^{-1}$ in 8641 channels at a ground resolution of $12 \mathrm{~km}$ (diameter) at nadir.

In Klüser et al. (2011), a methodology to retrieve mineral dust aerosol optical depth (AOD) from IASI observations was presented. This method uses singular vector decomposition (SVD) for un-mixing the signals of (mineral) aerosol, gas absorption and surface emissivity. Unlike classical principal component analysis (PCA), SVD is performed on the data (or observation) matrix directly and not on the covariance matrix. Mathematically it is the solution of the eigenvalue problem for a non-symmetric matrix.

The approach extracts the aerosol information from the spectral extinction (due to absorption and scattering by the aerosol) pattern matched to linear combinations of third and higher order singular vectors of IASI spectra.

The basic idea of the method is to apply a volcanic ash observation method which does not rely on a priori assumptions such as atmospheric state or surface emissivity. Following this constraint, no forward modelling of the radiance field is applied in this method. Nevertheless, one a priori assumption cannot be avoided - the use of spectral extinction properties of the observed aerosol (volcanic ash). For the observation of mineral dust over desert areas, extinction spectra of dust components measured in the laboratory by FTIR are used (Klüser et al., 2012; measurements of spectra described in Hudson et al., 2008a, b).

Instead of pre-calculating look-up tables generated by radiative transfer forward modelling, mineral aerosol related equivalent optical depth spectra are calculated in the 8-12 $\mu \mathrm{m}$ $\left(830-1250 \mathrm{~cm}^{-1}\right)$ window region (Klüser et al., 2011). For mathematical details of the retrieval algorithm the reader is referred to Klüser et al. (2011).

The IASI radiance spectra of the window region (830$1250 \mathrm{~cm}^{-1}$ ) are compiled into 42 bins with $10 \mathrm{~cm}^{-1}$ bin width (20 IASI channels each) with maximum brightness temperature of each bin being used in order to minimise the absorption effect of narrow gas absorption lines. Then the equivalent optical depth $\tau_{\text {eqv }}$ is calculated from the observed radiance $L_{\mathrm{obs}}$ at wavenumber $v$, the Planck-function $B_{v}$ of $T_{\text {base }}$, i.e. the maximum brightness temperature within the observation window (baseline temperature) and the cosine of the viewing zenith angle $\left(\Theta_{\mathrm{v}}\right)$ :

$L_{\mathrm{obs}}=e^{-\tau_{\text {eqv }} / \cos \left(\theta_{\mathrm{v}}\right)} B_{v}\left(T_{\text {base }}\right)$.

Singular vectors decomposed from IASI spectra of a sevenday period reflect the dominating modes of spectral variability in IASI spectra (Klüser et al., 2011).

The leading two singular vectors account for most variability in the IASI spectra and can be attributed to surface emissivity and broad gas absorption $\left(\mathrm{O}_{3}, \mathrm{H}_{2} \mathrm{O}, \mathrm{CO}_{2}\right)$. Consequently, the ash signal is carried mainly by the higher order singular vectors (numbers three to six). Projection of the normalised ash extinction spectrum onto the ash related spectral extinction signal, i.e. the linear combination of weighted higher order singular vectors, provides an estimate of the infrared optical depth of volcanic ash at $1000 \mathrm{~cm}^{-1}$ represented by the respective ash component (done for each component separately). The weighting of the different components is obtained from a least-squares fit between the theoretical AOD spectrum and the singular vector linear combination. From the AOD estimate the effective ash emission temperature can be estimated (Ackerman, 1997; Klüser et al., 2011). The observed radiance spectra are then corrected for the contribution of aerosol emission and a second iteration of the retrieval yields ash infrared AOD.

The validation of IASI derived desert dust AOD could be largely improved by the use of measured extinction spectra for different dust components compared to using OPAC spectra (Klüser et al., 2012). One of the major advantages of the singular vector-based un-mixing approach is that mineral aerosol can also be observed above land, where surface emissivity is unknown. Moreover, silicate aerosols can also be detected above underlying clouds.

Extinction spectra of desert dust and volcanic ash in the $8-12 \mu \mathrm{m}$ range have large similarity, as both are mainly 
composed of silicate materials (e.g. Volz, 1973). Nevertheless, mineralogy and particle sizes of volcanic ash may strongly differ from dust assumptions (Volz, 1973), especially regarding the apparent absence of clays and the higher feldspar abundance as well as the presence of mafic minerals (Pettijohn et al., 1972). Moreover, Hudson et al. (2008a, b) showed that the extinction spectra obtained from Mie calculations are significantly blue-shifted when compared to measured extinction spectra.

The continuous distribution of ellipsoids (CDE) approach for modelling the spectral absorption of aerosols (e.g. Hudson et al., 2008b) shows the best representation of spectral characteristics of the extinction spectra. Yet the approach only accounts for absorption and neglects scattering by the aerosol. While for small particles $(D \ll \lambda)$ this assumption does not result in large errors (see Yang et al., 2007; Laksina et al., 2012), for larger particles the single scattering albedo increases and the assumption breaks down. Nevertheless, Ackerman (1997) analysed the sensitivity of spectral variation of total extinction to scattering effects for desert dust under different conditions and also for volcanic ash. Scattering by volcanic ash was found to be spectrally invariant. In addition, Thomas and Gautier (2009) show for a quartz-rich dust storm over Africa that spectral variability of IR AOD is dominated by absorption. It is not clear if this is generally the case in volcanic ash (refractive indices of different ash components show rather large variability also of the real part for volcanic ash components, e.g. Pollack et al., 1973). Figure 1 shows the single-scattering albedo for plagioclase and orthoclase feldspars to be exemplarily. For both feldspars, three different size distributions inspired by the OPAC dust modes (Hess et al., 1998) are presented and single scattering albedo is calculated with Mie theory. As outlined above, for small particles single scattering albedo is very small (solid lines) and scattering effects can be neglected. For coarser particles scattering becomes more important and causes the broadening of the extinction peaks.

The eight mineral components used for ash retrieval together with their source of optical constants are presented in Table 1, while the resulting extinction spectra are depicted in Fig. 1. The selection of minerals is based on reports of mineralogical composition for Andean volcanoes indicating that their ash contains high fractions of quartz or silicate glass (like obsidian) and feldspars (e.g. Watt et al., 2009; Alfano et al., 2011). In contrast to many previous studies (e.g. Prata, 1989; Wen and Rose, 1994; Clarisse et al., 2010), no mineral spectra of "bulk ash compositions" have been used here in order to (be generally able to) account for variable fractions of distinct mineral components. The spectra of the different components are normalized by the integrated extinction over the retrieval domain $\left(833 \mathrm{~cm}^{-1}-1250 \mathrm{~cm}^{-1}\right.$, equals $8 \mu \mathrm{m}-12 \mu \mathrm{m}$ in wavelength space) in Fig. 1 for visualisation purposes.

The list of components is definitely not complete to consider all volcanic minerals. Due to the different mineralogies of volcanic ash from different regions or geological processes (e.g. subduction zones or mid-ocean ridges), it is not clear if one list of useful mineral components can be applied globally. However, eight components are sufficient for the retrieval of volcanic ash in reasonable computing time. They also provide enough spectral variability to search for the best fit in the observations. Apart from that, these spectra represent a selection of minerals with rather strong deviations in spectral features between each other compared to other minerals. Nevertheless, it is not envisaged or suggested that the retrieval components cover the full mineralogy of volcanic ash.

Furthermore, it is not claimed that the resulting mineralogical composition as calculated in the retrieval represents the true composition of the volcanic ash. As has been outlined above, the role of particle size on scattering properties of the ash has not been analysed in detail. Since no explicit forward modelling is used in the retrieval, it is difficult to perform an information content analysis by calculating averaging kernels (see e.g. Rodgers, 2000). The role of particle scattering on composition information content has to be investigated in more detail in the future. Gangale et al. (2010) conclude that ash retrievals from TIR sounders are sensitive to composition and particle size of the ash besides optical depth due to the reasons outlined above. Consequently, the best fit of components with variable extinction spectra can also be affected by the particle size distribution, representing scattering effects of larger ash particles (see also Salisbury and Wald, 1992). Although the mineral extinction models are selected to fit volcanic ash plumes, they also have to include silicates which are also abundant in desert dust (e.g. $\mathrm{SiO}_{2}$, feldspars). Thus, the retrieval will also be sensitive to airborne mineral dust.

Ice clouds can also be detected from IASI with the same method as the ash retrieval run with ice cloud optical properties (Warren, 1984). Information on ice clouds is used qualitatively only due to lacking validation.

\section{Observation and analysis of the ash plume}

Figure 2 shows the evolution of the PCCE ash plume during the initial phase of the eruption as seen in IASI AOD. The volcano is indicated in the maps by the white triangle near the plume origin in Chile. The plume evolution is depicted for each overpass of the MetOp satellite, i.e. at about 09:45 local time in the morning (descending orbits) and about 21:45 local time in the evening (ascending orbits). The retrieval has been limited to latitudes between $20^{\circ} \mathrm{S}$ and $60^{\circ} \mathrm{S}$ in order to reduce processing costs. Ash optical depth at $10 \mu \mathrm{m}$ reaches values of more than 1.5 in the plume center. The plume is covered very well by the IASI observations, although there are hardly any observations directly above the volcano. It is obvious that some lower mineral AOD observations over northern parts of Chile are not related to the PCCE plume 

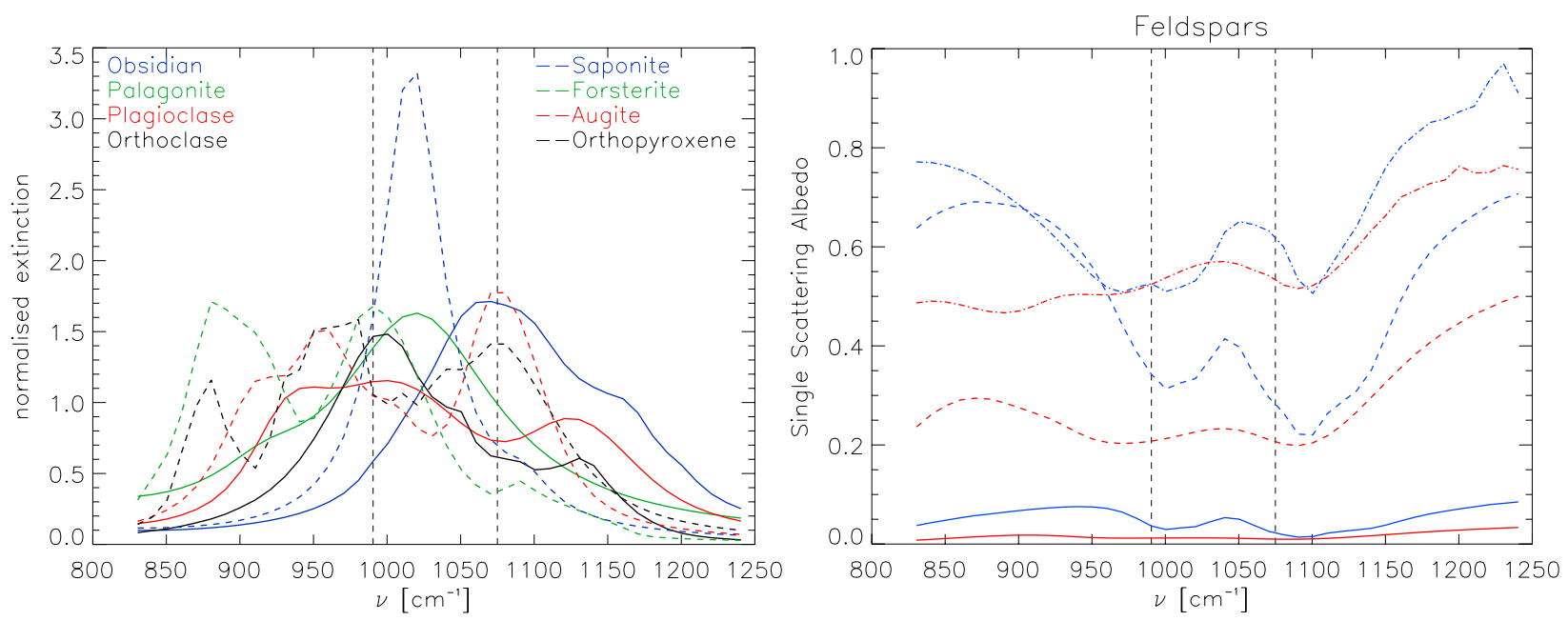

Fig. 1. Left: Extinction spectra of volcanic minerals in wavenumber $(v)$ space. The vertical dashed black lines delimit the ozone absorption band not used by the retrieval (see Klüser et al., 2011). Right: Single scattering albedo of the feldspars (plagioclase in red and orthoclase in blue) for three different size distributions inspired from OPAC dust modes (solid: nucleation mode, dashed: accumulation mode, dash-dot: coarse mode).
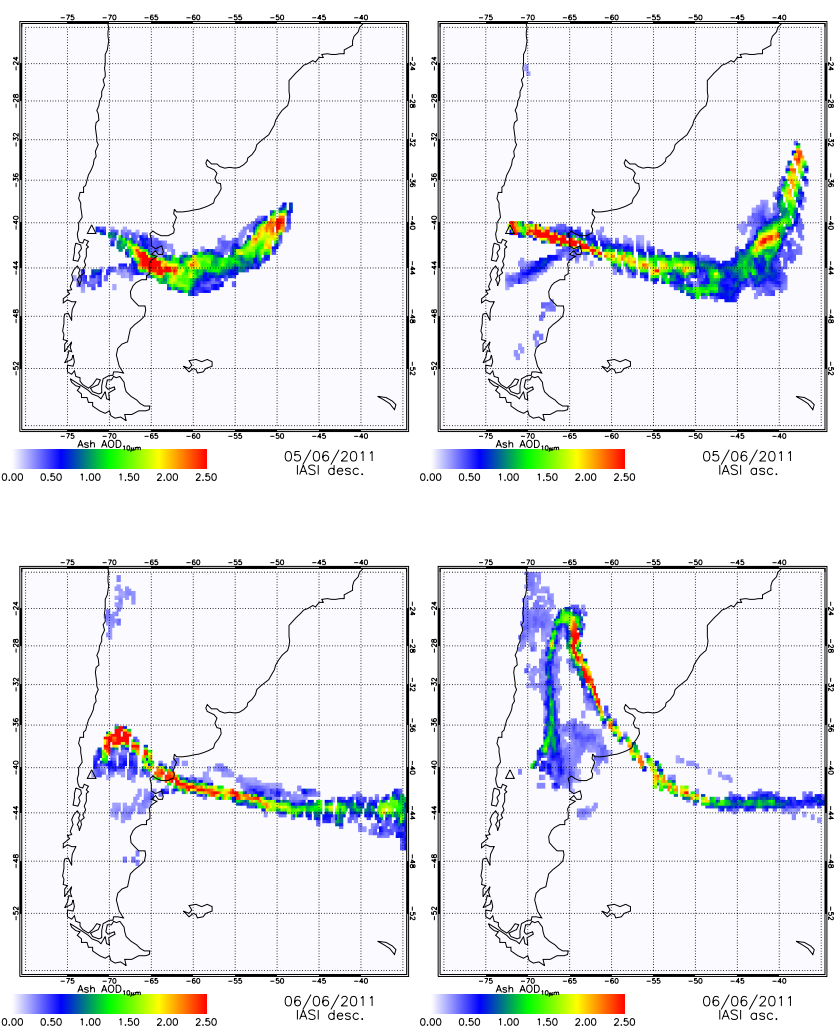

Fig. 2. Ash Optical Depth at $10 \mu \mathrm{m}$ of the PCCE plume for 5 through 6 June. Descending (desc.) orbits represent morning observations, ascending (asc.) orbits are from local evening. The black triangle indicates the position of the volcano.
Table 1. Mineral components used in the retrieval and source of optical constants.

\begin{tabular}{ll}
\hline Mineral & Source \\
\hline Obsidian & Koike et al. (1989) \\
Palagonite & Roush et al. (1991) \\
Bytownite (Plagioclase) & Aronson et al. (1979) \\
Orthoclase & Aronson (1986) \\
Saponite & Roush et al. (1991) \\
Forsterite (Olivine) & Servoin and Pirou (1973) \\
Augite (Clinopyroxene) & Aronson et al. (1979) \\
Orthopyroxene & Roush et al. (1991) \\
\hline
\end{tabular}

(especially on 6 June). These may well be observations of airborne desert dust.

Figure 3 shows the volcanic ash plume through the subsequent days (7 and 8 June). On 7 June, parts of the plume directly above the volcanic source and also north of $30^{\circ} \mathrm{S}$ are missed due to orbit gaps and ice clouds (see Fig. 4). The missed ash is advected further east and again detected at the Atlantic Ocean coast in the evening (visible on 8 June in Fig. 3).

With IASI it is not possible to retrieve volcanic ash AOD below or within ice clouds. Moreover, within the $12 \mathrm{~km}$ IASI pixels mixtures of ice and ash or ice coatings on ash particles may occur. Thus, one is also interested in the position and opacity of ice clouds. As a first assessment, resulting extinction spectra of the ash plume are mixed with ice cloud extinction spectra (Warren, 1984) for ice cloud contributions of $0 \%, 25 \%, 50 \%, 75 \%$ and pure ice cloud. For each ashice mixture the correlation coefficient between composed ash-ice extinction spectrum and observed linear combination 

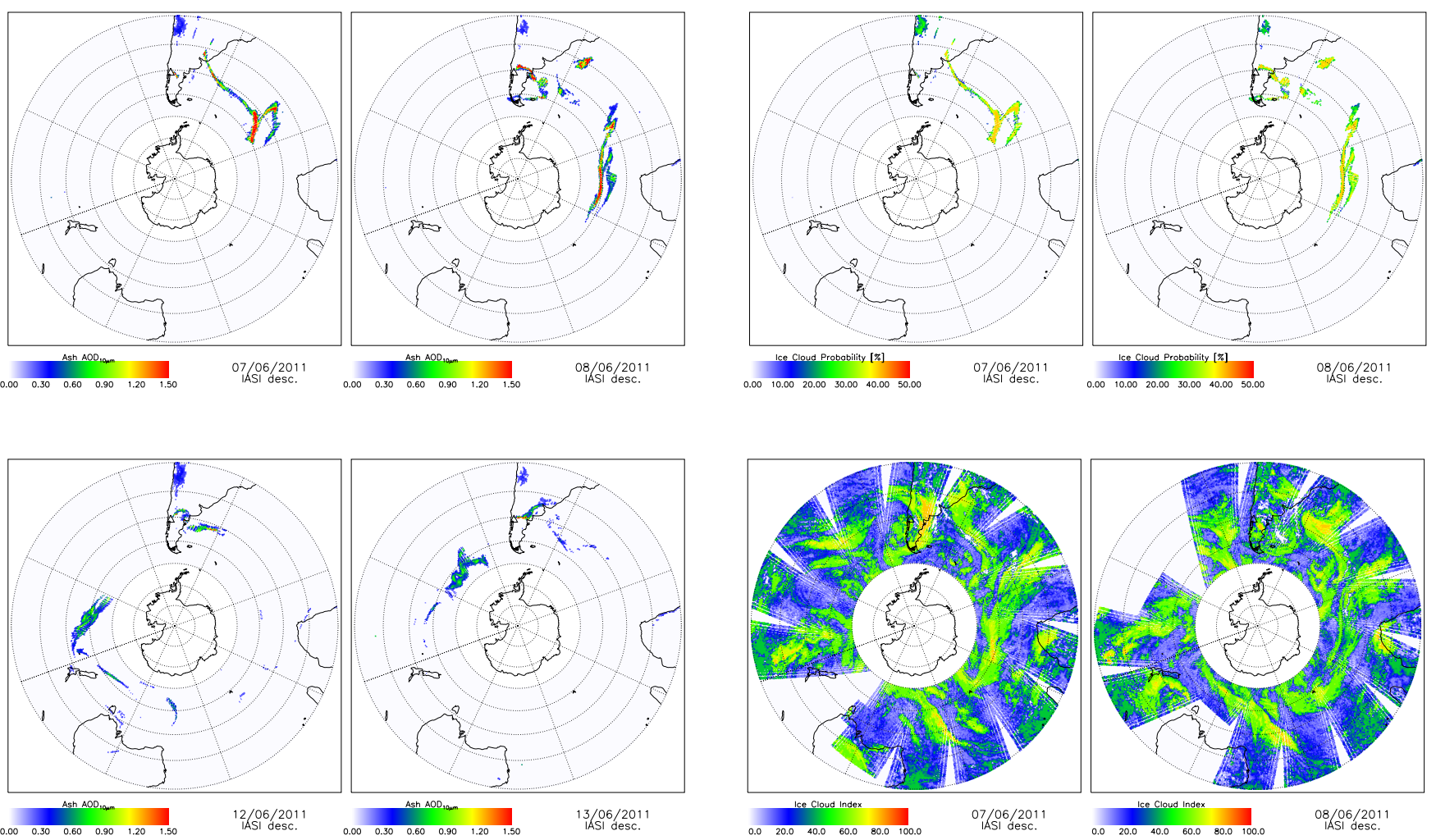

Fig. 3. The PCCE ash plume on its way around the Southern Hemisphere for descending MetOp orbits from 7, 8, 12 and 13 June.

of weighted singular vectors is calculated and the respective ice abundance is weighted with the normalized correlation, yielding the ice cloud probability for the respective pixel. Ice cloud probabilities within ash observations (with $\mathrm{AOD}_{10 \mu \mathrm{m}}>0.1$ only) are depicted in the top row of Fig. 4 for 7 and 8 June descending orbits. The ice cloud extinction spectra can be used to calculate an ice cloud index by correlating them to the IASI spectra (bottom row of Fig. 4). Index values above 50 (correlation times 100) indicate opaque ice clouds while lower values indicate potential thin ice cloud contamination of the observations. It is evident from Fig. 4 that in these cases the ash plume is transported very close to and potentially partly within or beneath ice clouds.

In order to examine the retrieval scheme for the PCCE event, the sensitivity of IASI aerosol optical depth thresholds and the maximum retrieval uncertainty is investigated. For the analysis the threshold values for aerosol optical depth are varied between 0.1 and 0.3 and the intrinsic retrieval uncertainty ranges between threshold values from $30 \%$ to $50 \%$. The results of the evaluation are summarized in Table 2. Selecting conservative criteria with retrieval uncertainties less than $30 \%$ and aerosol optical depths thresholds larger than 0.2 results in 1874 IASI observations for the PCCE event from June 5 to 14 . By applying these conservative criteria the

Fig. 4. Probability of ice crystals in ash plume for descending orbits of 7 and 8 June 2011 (top row) and ice cloud index for all IASI observations (bottom row).

noise level of the observational data can be reduced to a minimum. When selecting an even stricter threshold for aerosol optical depth of larger than 0.3 (and uncertainty less than $30 \%$ ), no ash observations remain for 11 June and 14 June.

All IASI observations are assigned to specific sources, i.e. the PCCE or mineral dust, by a simple source-receptor analysis using the backward trajectory-matching technique (Thomas et al., 2005). Following the sensitivity analysis above, all IASI ash observations with an aerosol optical depth larger than 0.2 and a retrieval uncertainty less than $30 \%$ from 5 June to 14 June are examined (1874 observations). Ensembles of backward trajectories are calculated using the threedimensional kinematic trajectory model FLEXTRA (Stohl et al., 1999), which is driven by wind fields from the Global Forecasting System (GFS) of the National Center for Environmental Prediction (NCEP) with a $6 \mathrm{~h}$ resolution interpolated to $3 \mathrm{~h}$. In order to attribute every single IASI observation to the PCCE or other potential emission sources, ensembles of backward trajectories are released at the satellite observation using the spatial and temporal characterization of the IASI observations as starting conditions. Trajectories are integrated backwards for $240 \mathrm{~h}$. Since the height of the ash plume in the (vertically integrated) observations 

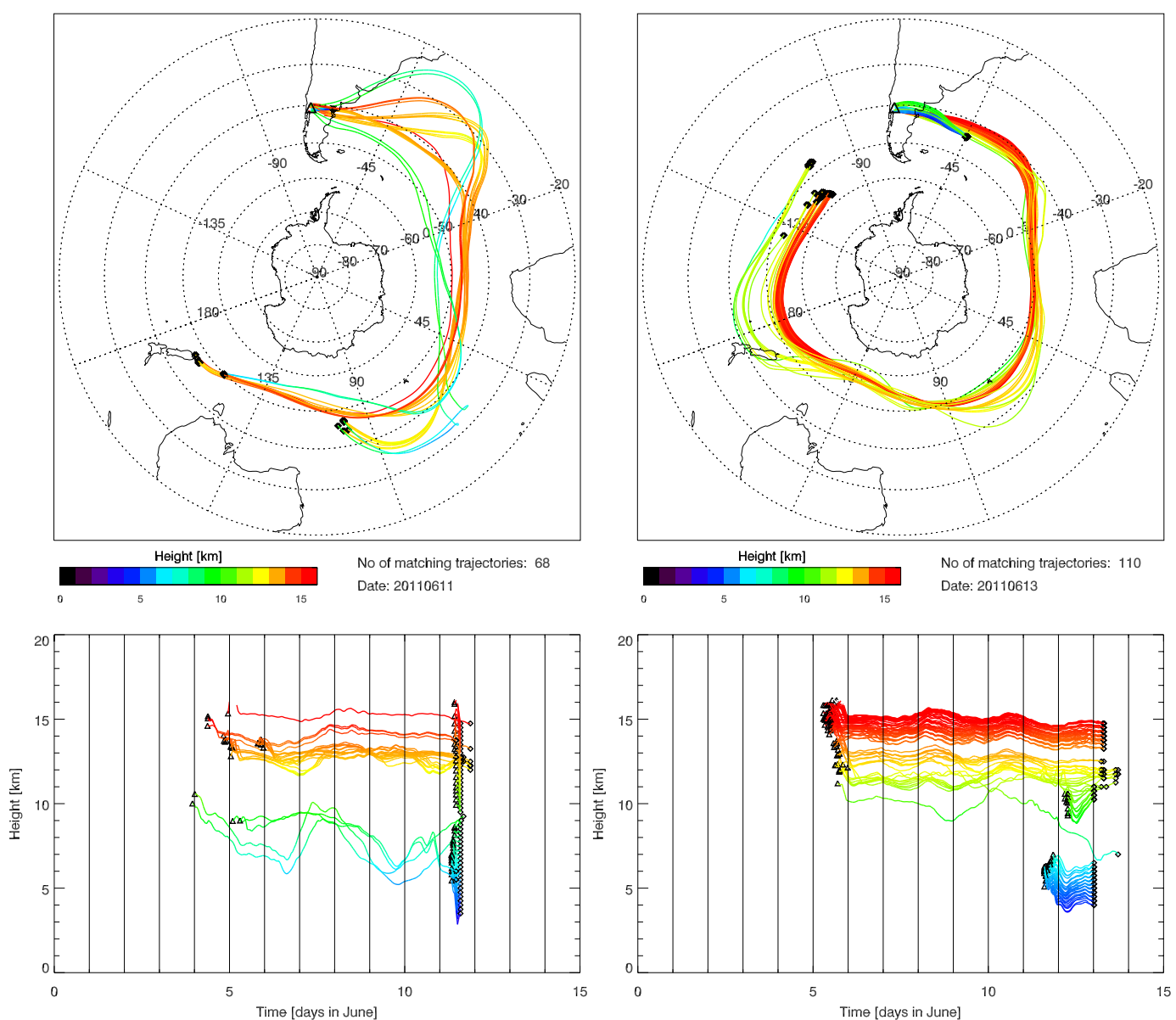

Fig. 5. Backward trajectories released for the IASI observations on 11 June (left) and 13 June (right) filtered for PCCE depicting the sourcereceptor relationship. In the bottom panel the matching backward trajectories are plotted as a function of height. The triangle symbolizes the volcano (source), the cross the observation (receptor where the backward trajectory was initialized). The observation time follows two groups, the ascending and descending orbit.

Table 2. Sensitivity of the number of IASI observations to aerosol optical depth thresholds (AOD) and maximum retrieval uncertainty (ERR) for the eruptive period from 5 June to 14 June 2011. For the analysis the threshold values for aerosol optical depth vary between 0.1 and 0.3 and the retrieval uncertainty between threshold values ranging from $30 \%$ to $50 \%$.

\begin{tabular}{lrrrrrrrrr}
\hline AOD & $>0.1$ & $>0.1$ & $>0.1$ & $>0.2$ & $>0.2$ & $>0.2$ & $>0.3$ & $>0.3$ & $>0.3$ \\
ERR & $>50 \%$ & $>40 \%$ & $>30 \%$ & $>50 \%$ & $>40 \%$ & $>30 \%$ & $>50 \%$ & $>40 \%$ & $>30 \%$ \\
\hline Date & $n_{\text {obs }}$ & & & & & & & & \\
\hline 5 Jun & 161 & 145 & 97 & 127 & 123 & 90 & 103 & 101 & 84 \\
6 Jun & 998 & 801 & 464 & 717 & 641 & 402 & 500 & 471 & 326 \\
7 Jun & 1089 & 942 & 630 & 729 & 667 & 456 & 460 & 449 & 309 \\
8 Jun & 1149 & 982 & 665 & 691 & 617 & 437 & 399 & 380 & 284 \\
9 Jun & 762 & 605 & 365 & 297 & 261 & 185 & 118 & 112 & 90 \\
10 Jun & 628 & 572 & 387 & 200 & 197 & 176 & 50 & 50 & 47 \\
11 Jun & 167 & 146 & 101 & 18 & 18 & 17 & 0 & 0 & 0 \\
12 Jun & 240 & 211 & 136 & 50 & 49 & 43 & 18 & 18 & 16 \\
13 Jun & 333 & 302 & 196 & 72 & 69 & 64 & 5 & 5 & 5 \\
14 Jun & 132 & 119 & 82 & 13 & 13 & 4 & 1 & 1 & 0 \\
\hline Total No. Obs & 5659 & 4825 & 3123 & 2914 & 2655 & 1874 & 1654 & 1587 & 1161 \\
\hline
\end{tabular}


is unknown, the trajectories are initialized every $250 \mathrm{~m}$ from $1 \mathrm{~km}$ to $15 \mathrm{~km}$ altitude. Filtering the resulting ensemble of trajectories for the PCCE source allows confirming the volcanic origin of the detected (ash) particles and excluding other sources. It enables estimation of the effective emission height over the volcano as well as the effective height of the ash plume using the vertical wind shear. The accuracy of the trajectory-matching approach was evaluated in Thomas et al. (2005) using ground-based measurements of $\mathrm{SO}_{2}$ and aerosols.

Figure 5 shows the backward trajectories released for all IASI observations as described above on 11 June and 13 June, filtered for PCCE. Please note that the highest trajectories are plotted on top. Despite a transport time of partly over $192 \mathrm{~h}$, ash observations can be assigned to the PCCE. The altitude range of the trajectories that can be traced back to an emission on 4 June and 5 June varies from 6 to $16 \mathrm{~km}$. The effective emission height for the initial eruption based on these selected observation dates can be assigned to 9 to $16 \mathrm{~km}$. Using the observations on $13 \mathrm{June}$, for the subsequent eruption on 11 June, altitude levels of the plume between 4 and $7 \mathrm{~km}$ are exhibited, while the effective emission height can be confined from 5 to $7 \mathrm{~km}$. The ash observations at $45^{\circ} \mathrm{W} / 40^{\circ} \mathrm{S}$ on 13 June originate from a repeat minor eruption on 12 June and can be assigned to altitude levels between 9 and $11 \mathrm{~km}$.

Coherent long-range transport of the ash plume can be seen for the whole period. The source-receptor analysis for 11 June still represents well the pronounced wind shear to the east of Chile that could be observed by IASI (see Fig. 2). Ensembles of trajectories stay coherent depending on the effective emission height.

Evaluating the results of the trajectory analysis described above, Fig. 6 shows the percentage of IASI observations per day that can be assigned to the PCCE source. The given dates refer to the date of observation. Despite the application of a simple source-receptor analysis and global wind fields it can be demonstrated that the majority of observations from 5 June to 12 June can be assigned to the PCCE. It is also evident that the numbers decrease with increasing travel time up to $216 \mathrm{~h}$ taking into account that the majority of ash was released on 5 to 6 June. However, the result is somewhat disturbed as such that continued ash emissions prevail till 13 June.

By means of analyzing all IASI observations between 5 June and 14 June with the backward trajectory-matching technique described above, the effective emission height for the PCCE is estimated. All trajectories arriving over the volcano in a $1^{\circ} \times 1^{\circ}$ grid box centered at the source are filtered and normalized trajectory densities derived as a function of time and altitude.

The estimated effective emission height for the volcanic ash at PCC is depicted in Fig. 7 and follows well the independent observations mainly from ground reported by SERNAGEOMIN (2011); the onset of the PCCE on 4 June,

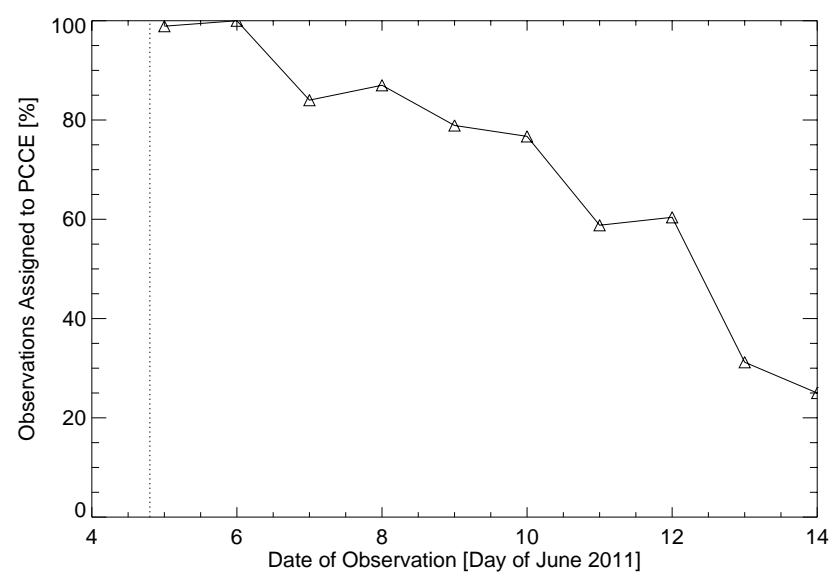

Fig. 6. Percentage of IASI observations per day that could be assigned to the PCCE source. The given dates refer to the date of observation. The dotted line indicates the onset of the eruption on 4 June 2011 at 19:15 UTC.

19:15 UTC, is captured (within the given temporal uncertainty of the wind fields: $6 \mathrm{~h}$ interpolated to $3 \mathrm{~h}$ resolution according to Stohl et al., 1999). On 4 June and 5 June the lower part ranging from 3 to $7 \mathrm{~km}$ (that was transported to the southeast) is well separated from an upper part above $9 \mathrm{~km}$ (that was transported to the east) (see Fig. 2). On 5 June an ash layer was observed by aircraft pilots at flight level 390/400 which corresponds to an altitude of approximately $12 \mathrm{~km}$. This can be recognized well in the Fig. 7 as maximum densities (given the uncertainties of the approach in particular to limitations in the vertical resolution). This is confirmed by local observatories which report an eruptive column of about 10 to $12 \mathrm{~km}$ height for 5 June. According to the reports from ground, the eruptive column lowers down to $10 \mathrm{~km}$ on 6 June (13:00 UTC). The subsequent eruptive phases on 7 June, 8 June, 11 June, and 13 June are also reproduced in the normalized trajectory densities above the volcano. The height regimes for the analyzed period are captured well, starting with an eruptive column exceeding $10 \mathrm{~km}$ but remaining below that level for the subsequent eruptions (when considering the maxima of the trajectory densities at the source). The maximum heights of the eruptive columns of the subsequent eruptions were estimated from ground to $7.5 \mathrm{~km}$ on 8 June, 4 and $8 \mathrm{~km}$ on 11 June, and $8 \mathrm{~km}$ on 13 June. The weak vertical structure of the analysis on 11 and 13 June indicates that some uncertainty is introduced by a missing or weak wind shear and in addition short travel times of the trajectories.

Derived emissions before the actual onset of the eruption clearly reflect further uncertainty introduced by the coarse resolution wind fields and thus the overall limitation and dependency on the quality of the wind fields.

Having confirmed the PCCE as the source of the majority of IASI observations with backward modelling, in a second step the Lagrangian Particle Dispersion Model FLEXPART 


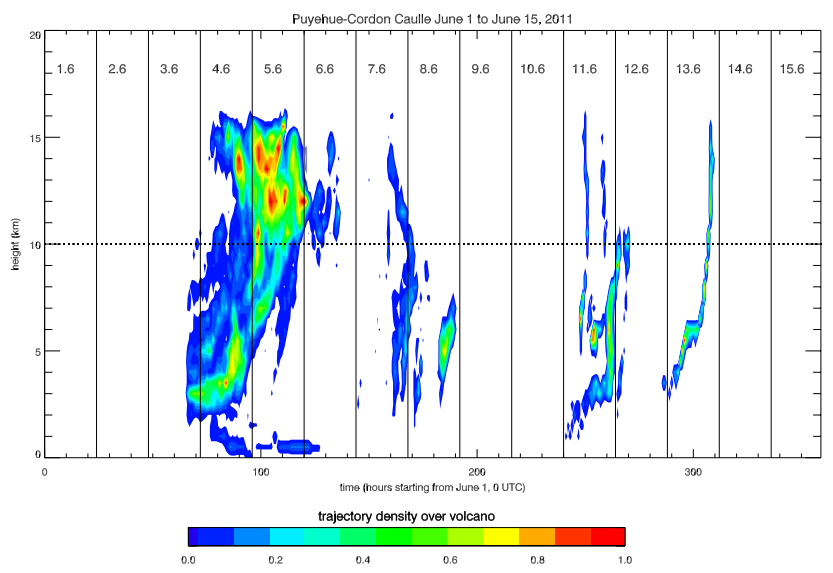

Fig. 7. Normalized trajectory density above PCC from 1 June to 15 June as indicator for the effective emission height of the volcanic ash derived by applying a source-receptor analysis using ensembles of backward trajectories.

(Stohl et al., 2005) has been applied to perform forward calculations. In contrast to the FLEXTRA model used for the backward trajectory analysis, the particle dispersion model FLEXPART is applied for forward calculations of air tracer advection. Moreover, sub-scale processes introducing increased dispersion as well as particle removal are considered. In our study, the particles are regarded as passive tracers; hence no chemical conversion takes place. Applying both FLEXTRA and FLEXPART can be used to prove the sourcereceptor relationship, including diffusion, and to derive a second estimate for the effective emission height, indicating uncertainties inherent in the trajectory modelling approaches.

For this study no a priori information is used for the FLEXPART simulations. Large amounts of particles with a unit mass were simulated to be emitted above Puyehue-Cordón Caulle from 2 to $14 \mathrm{~km}$ above ground in height level slices of $1000 \mathrm{~m}$. They are continuously released at a frequency of $6 \mathrm{~h}$ from 4 June to 13 June (the same time range covered by the FLEXTRA analysis). Such an approach has been introduced to study $\mathrm{SO}_{2}$ emission profiles of the Jebel at-Taïr eruption in 2007 (Eckhardt et al., 2008).

The dispersion model simulation is driven by the identical GFS forecasts which have been applied by the FLEXTRA analysis (already discussed above).

To derive the PCCE source vertical emission profile, all emitted particles are followed and continuously compared to IASI ash observations. Both the modelled particles and the IASI observations are binned into a $0.5^{\circ} \times 0.5^{\circ}$-grid. In the case that IASI observations agree with modelled particles in space and time, the release time and altitude of this model run is tagged with a certain score. The score depends linearly on the travel time of the air parcel and on the amount of binned pixels overlapping.

This implies that the score increases the longer the emission is dated back and the better the overlap of the modelled

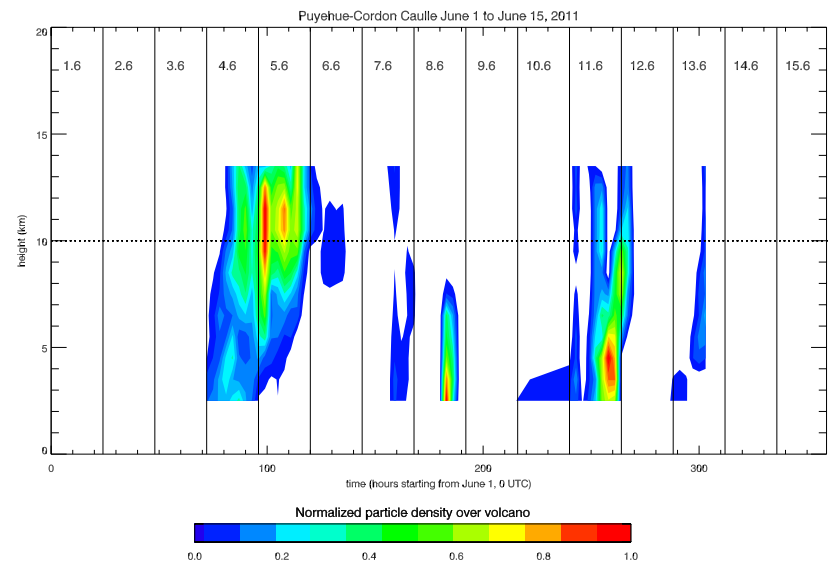

Fig. 8. Normalized particle density above PCC from 1 June to 15 June as indicator for the effective emission height of the volcanic ash derived by matching emitted particles with IASI observations.

particles with IASI observations is. Finally, the score is normalized for the three consecutive emission episodes of the PCCE individually, resulting in a quantity referred to as normalized particle density profile (see Fig. 8).

For the whole episode, 1354 agreements of modelled and observed particle bins are diagnosed. A total 38 bins of IASI ash observations cannot be matched modelled particles. Most of them are likely due to observations of desert dust.

Although the inversion by particle dispersion modelling is initialized at a much coarser vertical and temporal discretization, the key patterns in the effective emission profiles remain (when comparing Figs. 8 and 9). However, some deviations are obvious, like lower maximum emission heights in the initial eruption phase on 5 June and on 11 June.

\section{Discussion}

The IASI method is able to observe the evolution of the PCCE ash plume on a full cycle around the Southern Hemisphere. In contrast to methods using backscattered solar radiation, thermal infrared methods like the presented one for IASI are capable of observing the ash plume regardless of solar illumination. Consequently, the sampling rate can be doubled from polar orbiting platforms like MetOp.

In the setup used for volcanic ash retrieval the method has not yet been validated, thus the results rather show the potential of the method then quantitatively accurate results. One major limitation for validation is the lack of independent and reliable quantitative aerosol observations as, e.g. from the AERONET sunphotometer network (Holben et al., 1998), in the Southern Hemisphere and especially over the ocean where by far the most ash was observed by IASI. Applying the method originally developed for the observation of airborne desert dust to ash plumes from other volcanic eruptions with better coverage from ground based observations (e.g. the Eyjafjalla and Grimsvötn eruptions in 2010 and 
2011, respectively) will result in a quantitative evaluation of the application to volcanic ash in the future. Distinguishing volcanic ash from other aerosols remains an unsolved problem, especially for monitoring and alerting purposes. The IASI method has been shown to be sensitive to coarse mode, mainly silicate, aerosol particles only in the desert dust setup (Klüser et al., 2012). Thus, it can be assumed that the volcanic ash setup is also insensitive to other aerosol types such as industrial aerosols, biomass burning aerosol and sea salt. Nevertheless, it is not yet clear if a distinction between volcanic ash and desert dust will be possible with this method.

The current setup of the volcanic ash retrieval uses modelled extinction spectra. Hudson et al. (2008a, b) clearly showed that modelling extinction spectra, also with methods better suited than Mie theory, does not fully represent spectral variability of mineral extinction. Moreover, the role of scattering impacts on the extinction spectra is currently not fully addressed.

By means of ensemble backward trajectory-matching and forward Lagrangian particle dispersion modelling without using a priori information, the source-receptor relationship could be analyzed and the volcanic origin of the majority of the IASI observations proven. In doing so the effective emission height of the ash at PCC was estimated and an indication of the plume height could be derived. Therefore these approaches add information content to the vertically integrated IASI ash observations, which is very relevant for aviation safety and studies of stratospheric injections. A comparison with observations mainly from ground shows good agreement, given the use of global wind field at $6 \mathrm{~h}$ resolution.

Despite the existence of more sophisticated inversion schemes as applied in Stohl et al. (2011) for the eruption of Eyjafjalla in Iceland, these simple approaches have proven to be robust and efficient for the purpose of analyzing a qualitative source-receptor relationship in a near-real-time environment. Ensemble backward trajectory-matching and forward Lagrangian particle dispersion modelling methods are simple compared to a full inversion of the Lagrangian transport (Seibert et al., 2011) or adjoint retroplume approaches (Issartel and Baverel, 2003), which are still among the suite of applied methods (Baklanov et al., 2011).

However, all methods strongly rely on the vertical wind shear and depend on the quality of the wind fields. In this study, global wind fields from the Global Forecasting System (NCEP) at $6 \mathrm{~h}$ resolution interpolated to $3 \mathrm{~h}$ have been used. Kristiansen et al. (2012) have compared these wind fields to alternative data from the European Center for Medium Range Weather Forecast (ECMWF) and found that the source terms were robust to which meteorological data was used. Still the global data sets exhibit a coarse resolution compared to the pronounced orography in the Andes and the volcanic fissure of PCC in particular. Furthermore, micro- and meso-scale processes triggered by the eruption significantly influence the local meteorology. Seibert et al. (2011) conclude, however, that eruption column models are not a good alternative. Especially in near-real time and for volcanoes that are not monitored well, detailed knowledge of eruption source parameters is lacking. Since the focus in this study is on examining the hemispheric transport local effects at the volcano are not considered and global wind fields justified. As can be inferred from Figs. 6 and 7, however, the derived emission profiles prior to the actual onset of the eruption clearly reflect the uncertainty introduced by the coarse resolution wind fields and thus the overall limitation of the inversion methods.

\section{Conclusion and outlook}

A method previously developed for desert dust remote sensing with IASI has been adapted for retrieving infrared optical depth of volcanic ash plumes. The presented application of thermal infrared observations enables to observe ash plumes twice daily over land, over ocean and also above low-level clouds. The volcanic ash retrieval method uses extinction spectra of different mineral components found in volcanic ash rather than fixed "bulk-ash" refractive indices. As spherical Mie calculations cause significant errors in positions and strengths of Si-O resonance peaks the extinction spectra are modelled with non-spherical approximations. The different mineralogical components are weighted by a Singular Vector based projection scheme also accounting for surface emissivity effects in the observed radiance.

By applying the novel IASI retrieval scheme the plume of the 2011 Puyehue-Cordón Caulle eruption (PCCE) could be tracked along its circum-polar transport in the Southern Hemisphere from 5 June to 14 June. On 14 June parts of the ash emitted by PCCE arrived again at the source region from westerly directions. The IASI observations were examined by means of ensembles of backward trajectories and forward particle dispersion modelling without using a priori information. In doing so, the source-receptor relationship could be analyzed and the volcanic origin of the majority of the IASI observations proven. In addition, the effective emission height of the ash at the volcano through the different eruption phases was estimated and an indication of the plume height could be derived. A comparison with observations mainly from ground, as reported by SERNAGEOMIN (2011), shows fairly good agreement, given the use of global winds fields at $6 \mathrm{~h}$ resolution and the dependency on vertical wind shear. While the ash was repeatedly emitted into the troposphere at height levels between $3 \mathrm{~km}$ and $9 \mathrm{~km}$, during the peak of the eruption on 5 June the ash was possibly emitted up to $15 \mathrm{~km}$. Both methods clearly indicate an emission peak between $9 \mathrm{~km}$ and $14 \mathrm{~km}$. Observations from aircraft report ash at flight levels around $12 \mathrm{~km}$ (SERNAGEOMIN, 2011). Although two simple modelling approaches were applied, information content is added to the vertically integrated IASI ash observations, which is very relevant for aviation safety and studies of stratospheric injections. 
The focus of the source-receptor analyses performed here has been to examine the IASI retrievals qualitatively with respect to distinguishing between mineral dust and volcanic ash. Supplementary, the potential of retrieving additional characteristics of the eruption like effective emission height and plume height has been demonstrated without addressing ash concentrations.

In general, more quantitative methods to better consider and evaluate ash concentrations and their uncertainty are needed. A close collaboration between remote sensing and atmospheric modelling is essential to further characterize and elaborate the uncertainties in both observations and analysis, and to improve the derivation of the source function for volcanic ash. It is expected that the presented ash retrieval from IASI in combination with inversion modelling and data assimilation will significantly improve the reliability of ash plume forecasts for aviation safety.

The IASI ash retrieval presented here has been developed based on a scheme successfully used for remote sensing of mineral (desert) dust. Although desert dust and volcanic ash have large similarities insofar as they both are mainly composed of silicate minerals and occupy more or less the same particle size range, there are also differences like the specific mineralogy impacting on the refractive indices in the thermal infrared. Consequently, the evaluation results for desert dust cannot be regarded as being representative for the retrieval of volcanic ash AOD with IASI. Therefore a larger evaluation study of the method with respect to volcanic ash is envisaged, which will use observations of different volcanic eruptions and will exploit independent space-borne and ground-based observation capabilities. For example, independent information on the plume height, e.g. from space-borne LIDAR instruments will be applied to verify the height range obtained from the combination of IASI observations with Lagrangian modelling.

It will be investigated in the future if information on the separation between aeolian or volcanic origin of the aerosol can be derived from the satellite observations reliably. Moreover, in a subsequent evaluation study it will be investigated in detail how well optical depth and plume height (see Ackerman, 1997) are represented by a method which so far is only quantitatively evaluated for desert dust, and if visible optical depth can be derived reliably, which is largely controlled by particle size (e.g. Gangale et al., 2010) besides infrared optical depth. Generally, the interdependence of spectral extinction caused by particle size and by mineralogical composition has to be addressed further. A detailed information content analysis of the retrieval method considering its assumptions and the single scattering properties of ash particles needs to be performed at least over ocean, where surface emissivity can be assumed to be spectrally homogeneous. Such an analysis will contribute to proving if the signals resulting from particle size and composition can be distinguished by this retrieval method.
Acknowledgements. We are thankful to EUMETSAT and the EUMETSAT Data Centre (UMARF) for providing the IASI observations from METOP. We kindly acknowledge Andreas Stohl and all contributing colleagues for providing the models FLEXTRA and FLEXPART. Further thanks to the National Center for Environmental Prediction (NCEP) for making available the meteorological data of the Global Forecasting System (GFS). Moreover, we express our thanks to two anonymous reviewers and F. Prata for their very constructive comments, which helped to increase the quality of this paper.

Edited by: R. Schofield

\section{References}

Ackerman, S. A.: Remote sensing of aerosol using satellite infrared observations, J. Geophys. Res., 102, 17069-17079, 1997.

Alfano, F., Bonadonna, C., Volentik., A. C. M., Connor, C. B., Watt, S. F. L., Pyle, D. M., and Connor, L. J.: Tephra stratigraphy amd eruptive volume of the May, 2008, Chaitén eruption, Chile, B Volcanol., 73, 613-630, 2011.

Aronson, J. R.: Optical constants of monoclinic anisotropic crystals: orthoclase, Spectrochim. Acta A, 42, 187-190, 1986.

Aronson, J. R., Emslie, A. G., Smith, E. M., and Strong, P. F.: Infrared spectra of lunar soils and related optical constants, Proc. Lunar Planet. Sci. Conf., 10, 1787-1795, 1979.

Baklanov, A., Aloyan, A., Mahura, A., Arutyunyan, V., and Luzan, P.: Evaluation of source receptor relationship for atmospheric pollutants using approaches of trajectory modelling, cluster, probability fields analyses and adjoint equations, Atmospheric Pollution Research, 2, 400-408, doi:10.5094/APR.2011.045, 2011.

Clarisse, L., Coheur, P. F., Prata, A. J., Hurtmans, D., Razavi, A., Phulpin, T., Hadji-Lazaro, J., and Clerbaux, C.: Tracking and quantifying volcanic $\mathrm{SO}_{2}$ with IASI, the September 2007 eruption at Jebel at Tair, Atmos. Chem. Phys., 8, 7723-7734, doi:10.5194/acp-8-7723-2008, 2008.

Clarisse, L., Hurtmans, D., Prata, A. J. Karagulian, F., Clerbaux, C., Mazière, M. D., and Coheur, P.-F.: Retrieving radius, concentration, optical depth, and mass of different types of aerosols from high-resolution infrared nadir spectra, Appl. Optics, 49, 37133722, 2010.

Clarisse, L., Coheur, P.-F., Prata, F., Hadji-Lazaro, J., Hurtmans, D., and Clerbaux, C.: A unified approach to aerosol remote sensing and type specification in the infrared, Atmos. Chem. Phys. Discuss., 12, 26871-26928, doi:10.5194/acpd-12-26871-2012, 2012.

Corradini, S., Merucci, L., and Prata, A. J.: Retrieval of $\mathrm{SO}_{2}$ from thermal infrared satellite measurements: correction procedures for the effects of volcanic ash, Atmos. Meas. Tech., 2, 177-191, doi:10.5194/amt-2-177-2009, 2009.

Eckhardt, S., Prata, A. J., Seibert, P., Stebel, K., and Stohl, A.: Estimation of the vertical profile of sulfur dioxide injection into the atmosphere by a volcanic eruption using satellite column measurements and inverse transport modeling, Atmos. Chem. Phys., 8, 3881-3897, doi:10.5194/acp-8-3881-2008, 2008.

Gangale, G., Prata, A. J., and Clarisse, L.: The infrared spectral signature of volcanic ash determined from high-spectral resolution 
satellite measurements, Remote Sens. Environ., 114, 414-425, 2010.

Halmer, M. M. and Schmincke, H.-U.: The impact of moderatescale explosive eruptions on stratospheric gas injections, B. Volcanol., 65, 433-440, 2003.

Hess, M., Koepke, P., and Schult, I.: Optical Properties of Aerosols and Clouds: The Software Package OPAC, B. Am. Meteorol. Soc., 79, 831-844, 1998.

Hilger, D. W. and Clarke, J. D.: Prinicipal Component Analysis of MODIS for volcanic ash Part most important bands and implications for future GOES campaigns, J. Appl. Meteorol., 41, 9851001, 2002.

Holben, B. N., Eck, T. F., Slutsker, I., Tandré, D., Buis, J. P., Setzer, A., Vermote, E., Reagan, J. A., Kaufman, Y. J., Nakajima, T., Lavenu, F., Jankowiak, I., and Smirnov, A.: AERONET - a federated instrument network and data archive for aerosol characterization, Remote Sens. Environ., 66, 1-16, 1998.

Horwell, C. J. and Baxter, P. J.: The respiratory health hazards of volcanic ash: a review for volcanic risk mitigation, B. Volcanol., 69, 1-24, 2006.

Hudson, P. K., Young, M. A., Kleiber, P. D., and Grassian, V. H.: Coupled infrared extinction spectra and size distribution measurements for several non-clay components of mineral dust aerosol (quartz, calcite and dolomite), Atmos. Environ., 42, 5991-5999, 2008a.

Hudson, P. K., Gibson, E. R., Young, M. A., Kleiber, P. D., and Grassian, V. H.: Coupled infrared extinction and size distribution measurements for several clay components of mineral dust aerosol, J. Geophys. Res., 113, D01201, doi:10.1029/2007JD008791, 2008b.

Issartel, J.-P. and Baverel, J.: Inverse transport for the verification of the Comprehensive Nuclear Test Ban Treaty, Atmos. Chem. Phys., 3, 475-486, doi:10.5194/acp-3-475-2003, 2003.

Karagulian, F., Clarisse, L., Clerbaux, C., Prata, A. J., Hurtmans, D., and Coheur, P. F.: Detection of volcanic $\mathrm{SO}_{2}$, ash and $\mathrm{H}_{2} \mathrm{SO}_{4}$ using the Infrared Atmospheric Sounding Interferometer (IASI), J. Geophys. Res., 115, D00L02, doi:10.1029/2009JD012786, 2010.

Klüser, L., Martynenko, D., and Holzer-Popp, T.: Thermal infrared remote sensing of mineral dust over land and ocean: a spectral SVD based retrieval approach for IASI, Atmos. Meas. Tech., 4, 757-773, doi:10.5194/amt-4-757-2011, 2011.

Klüser, L., Kleiber, P., Holzer-Popp, T., and Grassian, V. H.: Desert dust observation from space - application of measured mineral component infrared extinction spectra, Atmos. Environ., 54, 419-427, doi:10.1016/j.atmosenv.2012.02.011, 2012.

Koike, C., Hasegawa, H., Asada, N., and Komatuzaki, T.: Optical constants of fine particles for the infrared region, Mon. Not. R. Astron. Soc., 239, 127-137, 1989.

Kristiansen, N. I., Stohl, A., Prata, A. J., Bukowiecki, N., Dacre, H., Eckhardt, S., Henne, S., Hort, M. C., Johnson, B. T., Marenco, F., Neininger, B., Reitebuch, O., Seibert, P., Thomson, D. J., Webster, H. N., and Weinzierl, B.: Performance assessment of a volcanic ash transport model mini-ensemble used for inverse modeling of the 2010 Eyjafjallajökull eruption, J. Geophys. Res., 117, D00U11, doi:10.1029/2011JD016844, 2012.

Krotkov, N. A., Carn, S. A., Krueger, A. J., Bhartia, P. K., and Yang, K.: Band Residual Difference algorithm for retrieval of $\mathrm{SO}_{2}$ from the Aura Ozone Monitoring Instrument (OMI),
IEEE T. Geosci. Remote, AURA Special Issue, 44, 1259-1266, doi:10.1109/TGRS.2005.861932, 2006.

Krueger, A. J.: Sighting of El Chichon sulfur dioxide clouds with the Nimbus 7 total ozone mapping spectrometer, Science, 220 , 1377-1379, 1983.

Larar, A. M., Smith, W. L., Zhou, D. K., Liu, X., Revercomb, H., Taylor, J. P., Newman, S. M., and Schlüssel, P.: IASI spectral radiance validation inter-comparisons: case study assessment from the JAIVEx field campaign, Atmos. Chem. Phys., 10, 411-430, doi:10.5194/acp-10-411-2010, 2010.

Laksina, O., Young, M. A., Kleiber, P. D., and Grassian, V. H.: Infrared extinction spectra of mineral dust aerosol: Single components and complex mixtures, J. Geophys. Res., 117, D18210, doi:10.1029/2012JD017756, 2012.

Loyola, D., van Geffen, J., Valks, P., Erbertseder, T., Van Roozendael, M., Thomas, W., Zimmer, W., and Wißkirchen, K.: Satellite-based detection of volcanic sulphur dioxide from recent eruptions in Central and South America, Adv. Geosci., 14, 3540, doi:10.5194/adgeo-14-35-2008, 2008.

Miller, T. P. und Casadevall, T.: Volcanic ash hazards to aviation, in: Encyclopedia of volcanoes, edited by: Sigurdsson, H., Academic Press, San Diego, California, USA, 2000.

Pettijohn, F. J., Potter, P. E., and Siever, R.: Sand and Sandstone, Springer Verlag, New York, USA, 1972.

Pollack, J. B., Toon, O. B., and Khare, B. N.: Optical properties of some terrestrial rocks and glasses, Icarus, 19, 372-389, 1973.

Prata, A. J.: Observations of volcanic ash clouds in the 10-12 $\mu \mathrm{m}$ window using AVHRR/2 data, Int. J. Remote Sens., 10, 751-761, 1989.

Prata, A. J. and Kerkmann, J.: Simultaneous retrieval of volcanic ash and SO2 using MSG-SEVIRI measurements, Geophys. Res. Lett., 34, L05813, doi:10.1029/2006GL028691, 2007.

Rix, M., Valks, P., Hao, N., van Geffen, J., Clerbaux, C., Clarisse, L., Coheur, P.-F., Loyola, D., Erbertseder, T., Zimmer, W., and Emmadi, S.: Satellite monitoring of volcanic sulfur dioxide emissions for early warning of volcanic hazards, IEEE J. Sel. Top Appl., 2, 196-206, 2009.

Rodgers, C. D.: Inverse methods for atmospheric sounding, Theory and practice, in: Series on Atmospheric, Oceanic and Planetary Physics, Vol. 2, World Scientific Publishing, Singapore, 2000.

Roush, T., Pollack, J., and Orenberg, J.: Derivation of Midinfrared (5-25 $\mu \mathrm{m})$ optical constants of some silicates and palagonite, Icarus, 94, 191-208, 1991.

Salisbury, J. W. and Wald, A.: The role of volume scattering in reducing spectral contrast of reststrahlen bands in spectra of powdered minerals, Icarus, 96, 121-128, 1992.

Seibert, P., Kristiansen, N. I., Richter, A., Eckhardt, S., Prata, A. J., and Stohl, A.: Uncertainties in the inverse modelling of sulphur dioxide eruption profiles, Geomatics, Natural Hazards and Risk, 2, 201-216, 2011.

SERNAGEOMIN (Servicio Nacional de Geologia y Mineria): Reportes Escpeciales de Actividad Volcanica No. 27-39, Observatorio Volcanologico des los Andes del Sur (OVDAS), Red Nacional de Vigilancia Volcanica (RNVV), available at: http://www.sernageomin.cl/volcan.php?iId=38 (last access: June 2012), 2011.

Servoin, J. L. and Piriou, B.: Infrared reflectivity and raman scattering of $\mathrm{Mg} 2 \mathrm{SiO} 4$ single crystal, Phys. Status Solidi. B, 55, 677$686,1973$. 
Stohl, A., Haimberger, L., Scheele, M., and Wernli, H.: An intercomparison of results from three trajectory models, Meteorol. Appl., 8, 127-135, 1999.

Stohl, A., Forster, C., Frank, A., Seibert, P., and Wotawa, G.: Technical note: The Lagrangian particle dispersion model FLEXPART version 6.2, Atmos. Chem. Phys., 5, 2461-2474, doi:10.5194/acp-5-2461-2005, 2005.

Stohl, A., Prata, A. J., Eckhardt, S., Clarisse, L., Durant, A., Henne, S., Kristiansen, N. I., Minikin, A., Schumann, U., Seibert, P., Stebel, K., Thomas, H. E., Thorsteinsson, T., Tørseth, K., and Weinzierl, B.: Determination of time- and height-resolved volcanic ash emissions and their use for quantitative ash dispersion modeling: the 2010 Eyjafjallajökull eruption, Atmos. Chem. Phys., 11, 4333-4351, doi:10.5194/acp-11-4333-2011, 2011.

Swanson, S. E. and Beget, J.: Melting properties of volcanic ash, in: Volcanic ash and aviation safety - Proceedings of the First International Symposium on Volcanic Ash and Aviation Safety, US Geological Survey Bulletin 2047, Seattle, Washington, USA., 1991.

Thomas, M. and Gautier, C.: Investigations of the March 2006 Africa dust storm using ground-based column-integrated high spectral resolution infrared $(8-13 \mu \mathrm{m})$ and visible aerosol optical thickness measurements: 2. Mineral aerosol mixture analysis, J. Geophys. Res., 114, D14209, doi:10.1029/2008JD010931, 2009.

Thomas, W., Erbertseder, T., Ruppert, T., van Roozendael, M., Verdebout, J., Meleti, C., Balis, D., and Zerefos, C.: On the retrieval of Volcanic Sulfur Dioxide Emissions from GOME backscatter measurements, J. Atmos. Chem., 50, 295-320, 2005.

Torres, O., Bhartia, P. K., Herman, J. R., Ahmad, Z., and Gleason, J.: Derivation of aerosol properties from satellite measurements of backscattered ultraviolet radiation, Theoretical basis, J. Geophys. Res., 103, 17099-17110, 1998. van Geffen, J., van Roozendael, M., Di Nicolantonio, W., Tampellini, L., Valks, P., Erbertseder, T., and van der A, R.: Monitoring of volcanic activity from satellites as part of the GMES Service Element Atmosphere (PROMOTE), Proceedings of the ENVISAT Symposium, 23-27 April 2007, Montreux, Switzerland, ESA publication SP-636, 2007.

Volz, F. E.: Infrared optical constants of ammonium sulphate, Sahara dust, volcanic pumice, and flyash, Appl. Optics, 12, 564 $568,1973$.

Warren, S. G.: Optical constants of ice from the ultraviolet to the microwave, Appl. Optics, 23, 1206-1225, 1984.

Watt, S. F. L., Pyle, D. M., Mather, T. A., Martin, R. S., and Matthews, N. E.: Fallout and distribution of volcanic ash over Argentina following the May 2008 explosive eruption of Chaiten, Chile, J. Geophys. Res., 114, B04207, doi:10.1029/2008JB006219, 2009.

Wen, S. and Rose, W. I.: Retrieval of sizes and total masses of particles in volcanic clouds using AVHRR channels 4 and 5, J. Geophys. Res., 99, 5421-5431, 1994.

Yang, P., Feng, Q., Hong, G., Kattawar, G. W., Wiscombe, W. J., Mishchenko, M. I., Dubovik, O., Laszlo, I., and Sokolik, I. N.: Modelling of the scattering and radiative properties of nonspherical dust-like aerosols, J. Aerosol Sci., 28, 995-1014, 2007.

Zehner, C. (Ed.): Monitoring Volcanic Ash from Space, ESAEUMETSAT Workshop on the 14 April to 23 May 2010 eruption at the Eyjafjöll volcano, South Iceland, ESA/ESRIN, STM-280, 2010 . 